DOI:10.31696/2072-8271-2020-3-3-48-145-155

\title{
The Evolution of Relations between Myanmar and China in the 1990s: Results and Assessments
}

Wai Yan Phyo Naing

PhD Student, HSE University, Russia, Moscow, Myanmar, ywai@hse.ru, https://orcid.org/0000-0001-8358-1258

Abstract: The article gives insights in relations between Myanmar and China after Myanmar's generals seized power through a coup d'état in September 1988. As a result of repressions and the failed power transition to the opposition in 1990, the US and Europe imposed harsh economic sanctions on Myanmar's military government. This forced the Yangon to establish closer political and economic ties with Beijing. The author outlines the specificity of cooperation between Myanmar and China along the political-military, the economic and the social tracks with the focus upon discrepancies between the official and the grass-root levels. In the author's opinion, the growing imbalance between these dimensions accounted for the key vulnerability factor in the dialogue between the two countries.

Keywords: Myanmar-China relations, international sanctions, political ties, military dialogue, bilateral trade, Chinese migrants.

\section{Эволюция отношений между Мьянмой и Китаем в 1990-е гг.: результаты и оценки}

\section{Вей Ян Пьё Найнг}

аспирант НИУ ВШЭ, Россия, Москва, Мьянма, ywai@hse.ru https://orcid.org/0000-0001-8358-1258

Аннотация: В статье проанализирован характер отношений между Мьянмой и Китаем после военного переворота в Мьянме в сентябре 1988 года. В результате последовавших репрессий и несостоявшейся передачи власти оппозиции в 1990 г., США и государства Европы наложили жесткие экономические санкции на военное правительство Мьянмы. Это подтолкнуло Янгон к наращиванию политического и экономического сотрудничества с Пекином. Автор выявляет специфику сотрудничества между Мьянмой и Китаем по военно-политическому, экономическому и социальному направлениям, указывая на несоответствие между официальным и общественным низовым уровнями. Согласно позиции автора, растущее несоответствие между этими измерениями мьянманско-китайского диалога послужили основным фактором его уязвимости.

Ключевые слова: мьянманско-китайские отношения, международные санкции, политические связи, диалог по военной линии, двусторонняя торговля, китайские мигранты

(C) Wai Yan Phyo Naing, 2020. 


\section{Introduction}

In Myanmar, military leaders came to power in 1988, allegedly adhering to the principles of democratic reforms. In reality, in 1990 they usurped power in the country, refusing to transfer authority to the opposition party, National League for Democracy (NLD). As a result, the US and other Western countries imposed punitive sanctions on Myanmar's military junta. Therefore, Myanmar's government turned to the neighboring countries, mainly China, India and Thailand, for its economic and political survival. However, as Thailand and India supported the antiMyanmar armed groups in their respective border areas, this appeal did not bring the desired outcomes. This situation forced Myanmar to rely on China economically and politically, turning Myanmar into China's client state.

The period between 1990 to 2000 was aimed to lay down the foundations of Myanmar's domestic and foreign policy, including its relations with China. The article traces the lotic of political relations, bilateral trade and military ties between Myanmar and China and raises the following questions. Which factors drove the development of ties between the two countries? Was it really rather than declaratory the "golden time" in Myanmar-China relations, and how did leaders of the two countries contribute to it? Being a native of Myanmar, the author gives his answer premised upon a wide range of official sources, academic articles and his personal experience.

\section{The Political Dialogue: Upward Trends}

On 18 September 1988, Myanmar revealed its new political image to the world when the generals staged a coup d'etat. ${ }^{1}$ Later on, the State Law and Order Restoration Council (SLORC) was established, and the country changed its name from Burma to the Union of Myanmar ${ }^{2}$. Subsequently, the military government fell under harsh sanctions imposed by the US and Europe. ${ }^{3}$ Since Myanmar became isolated from the international community, the country naturally turned to its neighbors, among which the People's Republic of China (PRC) was of special significance.

Beijing recognized the SLORC immediately, declaring its policy of non-interference in Myanmar's domestic affairs. International researchers paid close attention to this important development as China was quick to establish robust bilateral relations with Myanmar. ${ }^{4}$ In fact, the two countries had made substantial progress in mutual dialogue be- 
fore the military takeover, because former Burmese Socialist Programme Party (BSPP) realized the urgency of economic reforms ${ }^{5}$.

The first bilateral meeting convened by the SLORC with Chinese counterparts embracing high-level officials and, most importantly, Myanmar's Trade Minister took place on 3 October in Yangon. ${ }^{6}$ It was followed by other exchanges of Myanmar's and China's officials: the SLORC's Vice-Chairman and the Commander-in-Chief (Army) Lieutenant General Than Shwe visited China on a goodwill trip to China on 18 October $1989 .^{7}$ He chaired a the 24-member delegation, which marked the first high-level Myanmar military delegation to Beijing since 1978. ${ }^{8}$ As Helene La Bail and Abel Tournier argued, "a partnership between the new Myanmar government and the PRC was quickly secured through the exchange of high-level diplomatic delegations." 9

On $20^{\text {th }}$ of August 1991, the Chairman of SLORC and Commander-in-Chief Senior General Saw Maung left for China for a five-days state visit invited by the President of the People's Republic of China Yang Shangkun. ${ }^{10}$ This was seen as a new diplomatic step in the development of the Sino-Myanmar relationship. During the meeting with Chinese Premier, the Senior General Saw Maung stated that "it has been over forty years that China and Myanmar have maintained Pauk-Phaw (kinsfolk) relationship. During this period, our two countries have enjoyed better understanding and greater cooperation with sympathy towards each other". ${ }^{11}$ Chinese Premier also said that "Our country and Myanmar are the ones which initiated and have adhered to the Five Principles of Peaceful Coexistence. Our Policy is to prevent interference in internal affairs of other countries." 12 After General Than Shwe became the Chairman of SLORC and the Head of State in April 1992, his government invited a high-level Chinese delegation led by the ViceChairmen of the Standing Committee of the National People's Congress Buhe to attend the completion ceremony of the Yangon-Thanlyin Bridge, which were constructed with the help of Chinese technicians. ${ }^{13}$

In a similar vein, the two countries decided to reopen Myanmar's Consulate-general office in Kunming and Chinese counterpart in Mandalay in August 1994. These offices had been closed after the 1967 antiChinese movement in Myanmar. ${ }^{14}$ As a founding leader of SLORC, the First Secretary Lieutenant General Khin Nyunt travelled to the Beijing at the invitation of the State Council of China, Secretary-General Luo Gan on 1st of September 1994. ${ }^{15}$ During his visit, Lieutenant General Khin Nyunt held a series of meetings with the PRC's Vice-President Rong Yiren, Premier Li Peng and other Chinese high-level officials. On 26 
December 1994, Chinese Premier Li Peng paid an official goodwill state-visit to Myanmar as reciprocating to the First Secretary of SLORC trip to China, and also honoring to the 40th anniversary of the Five Principles of Peaceful Coexistence. ${ }^{16}$ According to the Myanmar's official newspaper New Light of Myanmar, Premier Li Peng published a statement, according to which "my current visit is aimed at further strengthening the good unneighborly and friendly ties between us and expanding our mutually beneficial cooperation." Simultaneously, Myanmar's media also published a number of editorials and articles on $\mathrm{Mr} \mathrm{Li}$ Peng's visit. $^{17}$

Following this event, another milestone in state-level visits was marked by the trip to China made by the Senior General Than Shwe in January 1996. It was also his first-time foreign trip as a Head of State and Head of Government of the SLORC. ${ }^{18}$ According to Maung Aung Myoe, the aim was to inform the Chinese leaders of Myanmar's intention to join ASEAN. ${ }^{19}$ In discussions with the Chinese President, Senior General Than Shwe stressed that Myanmar was eager to join ASEAN but reiterated the "one-China policy" as a fundamental principle of Myanmar's diplomacy. ${ }^{20}$

After the establishment of ASEAN in 1967, China perceived it as the anti-Chinese and anti-communist political entity in the region. As a result, SLORC distanced itself from ASEAN until the mid-1990s. In its turn, Beijing changed its views on the association. Once the SLORC leaders received a green light from China and ASEAN states, Myanmar became a full-fledged ASEAN member in July 1997. ${ }^{21}$ Among SLORC's diplomatic success stories, fostering relations with China and ASEAN through constructive foreign policy initiatives, by means of this ensuring Myanmar's and SLORC's legitimacy in the international community, is worthy of note. At the same time, Myanmar's military leadership was aware that Yangon needed to reduce its dependence on Beijing. On 15 November 1997, the junta founded the State Peace and Development Council (SPDC). ${ }^{22}$ Since it retained the four top leaders of SLORC, the international community especially the US and other Western countries did not express any interest to cooperate. Simultaneously, Beijing solidified its positions as Myanmar's main partner.

On 4 June 1999, Lieutenant General Khin Nyunt made his first visit to China as the SPDC's First Secretary. During his trip, he participated in the signing ceremony of the "Agreement on Economic and Technical Cooperation between Myanmar and China", and also held a meeting with Chinese Premier Zhu Rongji. ${ }^{23}$ Nearly a year after the First 
Secretary's trip, on 31 May 2000 China's State Councilor Ismail Amet came to Yangon to celebrate the 50th anniversary of the establishment of the bilateral relations between Myanmar and China. ${ }^{24}$ Soon after the end of State Councilor's trip, in June 2000 the SPDC's Vice Chairman General Maung Aye went to Beijing at the invitation of China Vice President $\mathrm{Hu}$ Jintao. During his visit, he attended the signing of the "Framework of Future Bilateral Relations and Cooperation". As a reciprocate gesture, a month later China's Vice President $\mathrm{Hu}$ Jintao made a three-day visit to Myanmar, which resulted in three bilateral agreements. ${ }^{25}$

A separate track of cooperation between Myanmar and China accounted for fostering military ties. Since assuming power in 1988, Myanmar's military leaders have developed relations with China in all directions, which logically included military cooperation. During the SLORC Vice-chairman General Than Shwe trip to China, an agreement upon the purchase of Chinese arms worth nearly US\$ 1.4 billion was reached. ${ }^{26}$ Furthermore, Beijing provided training for Myanmar air force and army officers. Both Western and Myanmar scholars agreed that Myanmar had become a significant buyer of Chinese military hardware. ${ }^{27}$ In the early period of the 1990s, SLORC focused on issues like territorial integrity, national sovereignty and national reconsolidation. PRC was willing to provide Myanmar's military government with diplomatic and economic support, especially with an eye on Western sanctions. This resulted in a major rearmament of Myanmar's Armed Forces despite the Western embargo. ${ }^{28}$

At the same time, Chinese military leaders developed people-topeople contacts with Myanmar's generals. Examples include trips made by Deputy Chief of General Staff He Qizong in November 1991, Defence Minister Chi Haotan in July 1995, Vice-Chairman of the Central Military Commission Zhang Wannian in April 1996, and Chief of General Staff Headquarters General Fu Quangyou in April 2001 according to Tin Maung Maung Than. ${ }^{29}$ Myanmar leaders also conducted reciprocal trips to Beijing as part of bilateral military cooperation. Tellingly, the two countries agreed on training 300 officers from Myanmar Air Force and Navy in Chinese military staff colleges, as well as on extending an agreement on military and intelligence cooperation during the Vice Senior General Maung Aye's trip to Beijing in October $1996 .{ }^{30}$

Assessing the dynamics of Sino-Myanmar ties throughout the SLORC and SPDC era, the intensity of bilateral visits and the evolution of their leaders' personal relationship are noticeable. This came largely as a result of harsh sanctions imposed by the US and the West on My- 
anmar. No less importantly, since it was hard to attract foreign capital, China emerged as the top investor in Myanmar.

\section{Economic Cooperation: Reasons behind the Rapprochement}

A factor of high significance in cooperation between Myanmar and China accounted for economic cooperation. In fact, China was willing to capitalize upon Myanmar's international isolation. In its turn, Myanmar was willing to accept Chinese support, even at the expense of slipping into China's sphere of influence.

Myanmar's military leaders announced the "open-market" economy after they seized the state power, opening the first border trade office on 1 October $1988 .^{31}$ Simultaneously, the SLORC Trade Minister stressed that the Tatmadaw government expected to reach 300 million USD trade proficit in the fiscal year of 1988-89. ${ }^{32}$ As a result of the SLORC Vice-Chairman's visit to China in 1989, Chinese business missions intensified their trips to Myanmar. According to Beijing's statistics, in 1988, Myanmar's trade with China reached 270.71 million $\mathrm{USD}^{33}$ while in 1990 it accounted for 327.62 million $\mathrm{USD}^{34}$. However, China still was not the first country among Myanmar's major export partners while it became Myanmar's top importer. ${ }^{35}$

According to the Alistair D. B. Cook, in the early 1990s, Beijing encouraged Chinese companies to expand their presence in Myanmar in numerous sectors: the cultivation of tropical fruits, sugar cane, cassava and maize. The aim was to make all this tax-free for the Chinese market. $^{36}$ Therefore, the Sino-Myanmar bilateral trade steadily grew to reach 392.09 million USD in 1991. However, in Chinese statistics, the two countries trade reached 411 million USD in $1991 .^{37}$ Regardless these differences, Myanmar established the Jiegao Border Trade Economic Zone to improve the flow of goods. ${ }^{38}$

In 1992, SLORC also opened Muse, Namkham, Kyukok, Ho Pang, Chinshwehaw, Myitkyina, and Bhamo border trade checkpoints. As part of the same trend, the Yunnan officials declared De Hong as a frontier trade area, and 90 percent of China-Myanmar trade turnover originated there. ${ }^{39}$ In 1992, Myanmar's government permitted foreign direct investment from China. It stimulated both Chinese investment and trade: in 1992 and 1995, the trade turnover increased from 404 million USD ${ }^{40}$ to 816 million USD. ${ }^{41}$ In addition, as H. Le Bail and A. Tournier pointed out, the Ruili-Muse border area became the "lifeline of the Myanmar economy" when China renovated the Burma road. ${ }^{42}$ 
On 30 January 1996, the SPDC established "The Leading Committee for Promoting Economic Cooperation between the Union of Myanmar and the People's Republic of China. ${ }^{43}$ The First secretary of SPDC presided over the Committee and invited China's investments and economic cooperation to modernize Myanmar's industries and develop special economic zones. ${ }^{44}$ Simultaneously, the US and other Western countries introduced a new round of economic sanctions, cutting all investments in Myanmar in 1997. Atsuko Mizumo stated that "Myanmar economy gradually deepened its dependence on China". ${ }^{45}$ As a side effect of sanctions, Myanmar's exports gradually dropped in SinoMyanmar trade in 1997 and 1998 with 73.41 million USD and 62.04 million USD respectively. ${ }^{46}$ For the fiscal year of 1998, the bilateral trade reached the total value of 642 million USD, with China receiving a trade surplus of 452.82 million USD. ${ }^{47}$

On the other hand, the Myanmar-China Chamber of Commerce (MCCOC) re-energized its activity and embarked on a range of business and economic exchanges with China. Using Myanmar's local Chinese businesses became a way for Chinese companies to register as domestic firms. ${ }^{48}$ At the same time, cheap Chinese products also became attractive for Myanmar's low-income citizens. Therefore, the value of the SinoMyanmar trade slightly increased again in 1999 and 2000 with 508.21 million USD and 621.26 million USD respectively. ${ }^{49}$ However, the export-import parity was not achieved, and Beijing enjoyed the trade surplus of 371.62 million USD in 2000. But in overall terms, between 1990 and 2000 the bilateral trade increased nearly twofold, from 327.62 million USD to 621.26 million USD. ${ }^{50}$

In sum, economic relations between Myanmar and China were on the rise, the parties were motivated by geostrategic rather than by economic reasons. Myanmar's isolation was among the key incentives for Beijing to re-energize its policy. In its turn, Yangon, pressed by punitive sanctions, did not see any alternative to develop external cooperation rather than fostering economic and business ties with China. Like in politics, the top-down vector played the key role.

\section{The Social Dimension and the Chinese Migrants Factor}

For Myanmar, Beijing has a special diplomatic policy track aimed at promoting social and cultural ties. In the 1990s, the sacred journey "Dathasari" of the Buddha's Tooth Relic from China was the most important and valuable cultural exchange for both countries. On every oc- 
casion, Myanmar's government showed its reverence towards the arrival of the Buddha's Tooth Relic. ${ }^{51}$ Moreover, Beijing also sent cultural groups, sport teams, and members of Chinese writer and journalist associations to Myanmar. According to Maung Aung Myoe, "Since all social organizations were either sponsored or controlled by the state, China sent formal invitations through official channels only so that there would be no misunderstanding between the two governments." ${ }^{, 52}$

Myanmar became the first target for the Chinese migrants, especially from Yunnan Province. The cities of Upper Myanmar and Mandalay, the second-largest city of the country at that time, were growing, and the Chinese migrants bought the local's real estate. Experts pointed out that from 30 to 40 percent of Mandalay populations increased due to the Chinese immigration in 1990s. ${ }^{53}$ In the late 1990 s, over 5000 Chinese families based in Mandalay. The total population of Mandalay was about one million, and the Chinese migrants accounted for nearly 60,000 people. $^{54}$

Similar to Mandalay, in Shan State bordering with Thailand and China the population exploded between 1983 to 1993 by 16 percent due to Chinese migrant arrivals. In Hopang, Wa region, and Muse town the population increased by 52, 39 and 164 percent respectively. As a result, the Chinese language classes reopened in many cities such as Yangon and Mandalay. Meanwhile, Chinese rituals and beliefs in Taoism developed in Myanmar among the local Chinese communities. Tin Maung Maung Than mentioned that much of the economy has moved into Chinese hands with negative aftereffects for social stability. ${ }^{55}$ Since there was no government policy to relocate the Chinese migrants out of Mandalay and Upper Myanmar, anti-Chinese sentiments steadily grew in the local communities.

The social dimension of relations between Myanmar and China followed the same logic as the political-military and the economic track. At the same time, however, for Myanmar's military government to effectively monitor and regulate this direction was more difficult than the political-military and the economic ties. This factor meant that a strong uncertainty factor was gradually taking shape in the Myanmar-China dialogue.

\section{Conclusion}

An assessment of relations between Myanmar and China in the 1990s is hardly possible without addressing the memoirs of political figures who were in power and directly participated in elaborating on and 
implementing pivotal decisions on Myanmar's policy towards its great northern neighbor.

According to Min Zin, "after reading about a dozen of the former generals' memoirs, we can confidently conclude that the Burmese military generals don't trust the Chinese. "56 This assumption is premised on monographs published by former SLORC leading generals in 2006 and 2009 respectively. The military government exercised strict censorship rules on any publications around the 1990s to 2000s, so these books provide valuable insights into the mindset of Myanmar's military junta. Another author, General Khin Nyunt, in 2015 published his book focusing upon Beijing's trade and economic interests in Myanmar. ${ }^{57}$ In his view, the Myanmar military government's difficulties stemming from the US and European economic sanctions was the key factor of Myanmar-China rapprochement.

On the whole, the period from 1990-2000 heralded a remarkable success in the SPDC's policy towards China. Economic and business ties were cemented for the future development, largely due to positive outcomes of the top leaders' mutual visits. Judging by Myanmar's periodicals, large Burmese-Chinese businesses with substantial assistance from China were founded in Myanmar in the 1990s. It was also one of the reasons for the increase of Chinese migrants in Myanmar's big cities. Therefore, ties between China and Myanmar were strong.

Discouragingly, however, this existed only at the governmentto-government level. Since Myanmar locals did not support their military government, they saw Beijing as the key patron of the Tatmadaw regime. As a result, this resentment contributed to the growth of Sinophobia in the Myanmar both during and after the Tatmadaw government's rule.

\footnotetext{
${ }^{1}$ China's Policy Toward Myanmar: Challenges and Prospect, IDE-JETRO Institute of Developing Economics-Japan External Trade Organization, 2012, P.1, http://www.ide.go.jp/English/Research/Region/Asia/201209_kudo.html

2 Tin Maung Maung Than, Myanmar And China: A Special Relationship?, pp 189-210, ISEAS-Yusof Isak Institute, Southeast Asian Affairs, 2003, P. 189. URL: http://www.jstor.org/stable/27913234

${ }^{3}$ Ruju Gopalakrishnan, China's sway runs deep in Myanmar's ancient capital, World news, Reuters, 30 November 2011, URL: https://www.reuters.com/article/us-myanmarmandalay-idUSTRE7AT09720111130

${ }^{4}$ China's Policy Toward Myanmar: Challenges and Prospect... P. 1.

${ }^{5}$ Ibid., P. 9.

${ }^{6}$ The Working's People Daily Newspaper, 4.10.1988
} 
${ }^{7}$ Burma-China Chronology to 1999, Chronology complied by Burma Peace Foundation, September 1999. URL: http://www.ibiblio.org/obl/docs4/China-Burma_Chronology.pdf

${ }^{8}$ Maung Aung Myoe. In The Name of Pauk-Phaw: Myanmar's China Policy Since 1948, Institute of Southeast Asian Studies, Singapore, 2011, P. 144.

${ }^{9}$ Helene Le Bail and Abel Tournier, Form Kunming to Mandalay: The New "Burma

Road", Developments Along The Sino-Myanmar Border Since 1988, The Institut Francais des relations internationals, March 2010, P. 6, URL: http://www.burmalibrary.org/ docs08/IFRI av25lebailtourniere(en).pdf

${ }^{10}$ The Working People's Daily Newspaper, 15. 8. 1991

${ }^{11}$ Maung Aung Myoe. In The Name of Pauk-Phaw: Myanmar's China Policy... P. 111

${ }^{12}$ Burma-China Chronology to 1999, Chronology complied by Burma...

${ }^{13}$ New Light of Myanmar Newspaper, 31. 7. 1993

${ }^{14}$ Tin Maung Maung Than, Myanmar And China: A Special Relationship?... P. 196

${ }^{15}$ New Light of Myanmar Newspaper, 2. 9. 1994

${ }^{16}$ Maung Aung Myoe. In The Name of Pauk-Phaw: Myanmar's China Policy Since 1948, Institute of Southeast Asian Studies, Singapore, 2011, P. 112

${ }^{17}$ New Light of Myanmar Newspaper, 27. 12. 1994

${ }^{18}$ Helene Le Bail and Abel Tournier, Form Kunming to Mandalay:... P. 6.

${ }^{19}$ Maung Aung Myoe. In The Name of Pauk-Phaw: Myanmar's China Policy... P. 112

${ }^{20}$ New Light of Myanmar Newspaper, 14. 1. 1996

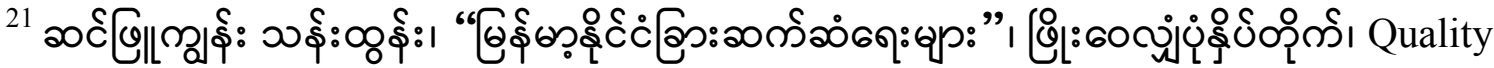

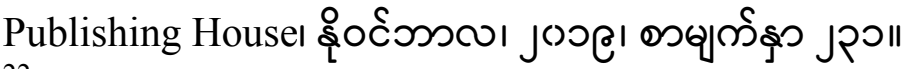

${ }^{22}$ Ibid., P. 251

${ }^{23}$ New Light of Myanmar Newspaper, 15. 11. 1999

${ }^{24}$ Maung Aung Myoe. In The Name of Pauk-Phaw: Myanmar's China Policy... P. 113

${ }^{25}$ Helene Le Bail and Abel Tournier, Form Kunming to Mandalay:... P. 6.

${ }^{26}$ Poon Kim Shee. The Political Economy of China-Myanmar Relations: Strategic and

Economic Dimensions, Ritsumeikan Annual Review of International Studies, Vol. 1, 2002, P. 37, URL: https://www.burmalibrary.org/docs2/Chinese_MM_Eco.pdf

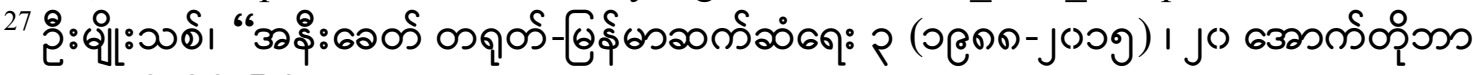
J

${ }^{28}$ Haccke. Jürgen. The Nature and Management of Myanmar's Alignment with China: The SLORC/SPDC Years, The Journal of Current Southeast Asian Affairs, Vol. 30, No. 2, P. 121, 2011, URL: https://journals.sub.uni-hamburg.de/giga/jsaa/article/view/447/445

${ }^{29}$ Tin Maung Maung Than, Myanmar And China: A Special Relationship?... P. 198

${ }^{30}$ Poon Kim Shee. The Political Economy of China-Myanmar Relations:... P. 37.

${ }^{31}$ Maung Aung Myoe. In The Name of Pauk-Phaw: Myanmar's China Policy... P.107.

${ }^{32}$ Burma-China Chronology to 1999, Chronology complied by Burma Peace Foundation...

${ }^{33}$ Maung Aung Myoe. In The Name of Pauk-Phaw: Myanmar's China Policy...P.152.

${ }^{34}$ Ibid., P.153

${ }^{35}$ Kudo Toshihiro. Myanmar's Economic Relations with China: Who benefits and who pay? ANU Press, 2008. URL: https://www.jstor.org/stable/j.ctt24hf5k.10.

${ }^{36}$ Alistair D. B. Cook. Myanmar's China Policy: Agendas, Strategies and Challenges. China Report, SAGE. Publication, Vol. 48, No. 2, 2012, P. 277 URL:

https://journals.sagepub.com/doi/pdf/10.1177/0009445512462745

${ }^{37}$ Tin Maung Maung Than, Myanmar And China: A Special Relationship?... P. 201 (Table 4).

${ }^{38}$ Helene Le Bail and Abel Tournier, Form Kunming to Mandalay:... P. 25. 
${ }^{39}$ Hongwei Fan, China's “Look South”: China-Myanmar Transport Corridor, Ritsumeikan International Affairs, Institute of International Relations and Area Studies, Ritsumeikan University, Vol.10, 2011, pp. 60, URL: http://r-

cube.ritsumei.ac.jp/bitstream/10367/3399/1/asia10_fan.pdf

${ }^{40}$ Tin Maung Maung Than, Myanmar And China: A Special Relationship?... P. 201.

${ }^{41}$ Hongwei Fan, China’s “Look South”: China-Myanmar Transport Corridor, Ritsumeikan International Affairs, Institute of International Relations and Area Studies, Ritsumeikan University, Vol.10, 2011, pp. 63, URL: http://r-

cube.ritsumei.ac.jp/bitstream/10367/3399/1/asia10_fan.pdf

${ }^{42}$ Helene Le Bail and Abel Tournier, Form Kunming to Mandalay:... P. 25.

${ }^{43}$ New Light of Myanmar Newspaper, 31. 1. 1996

${ }^{44}$ Tin Maung Maung Than, Myanmar And China: A Special Relationship?.. P. 203.

${ }^{45}$ Atsuko Mizumo. Economica Relations Between Myanmar and China, JICA Research Institute, Department of International Economy and Business, Faculty of Economics, Kyushu University, Japan, 2016, P. 198, URL: https://link.springer.com/chapter/10.1007/9784-431-55735-7_8.

${ }^{46}$ Maung Aung Myoe. In The Name of Pauk-Phaw: Myanmar's China Policy... P.152.

${ }^{47}$ Tin Maung Maung Than, Myanmar And China: A Special Relationship?... P. 201.

${ }^{48}$ Atsuko Mizumo. Economica Relations Between Myanmar and China... P. 206.

${ }^{49}$ Maung Aung Myoe. In The Name of Pauk-Phaw: Myanmar's China Policy... P.152

${ }^{50}$ Helene Le Bail and Abel Tournier, Form Kunming to Mandalay:... P. 14.

${ }^{51}$ Juliane Schober, Buddhist Just Rule and Burmese National Culture: State Patronage of The Chinese Tooth Relic in Myanmar, University of Chicago Press, History of Religions, Vol.36, No.3, Feb 1997, P. 222, URL:http://www.jstor.org/stable/3176458.

${ }^{52}$ Maung Aung Myoe. In The Name of Pauk-Phaw: Myanmar's China Policy... P. 122

${ }^{53}$ Helene Le Bail and Abel Tournier, Form Kunming to Mandalay:... P. 36.

${ }^{54}$ Ibid.

${ }^{55}$ Tin Maung Maung Than, Myanmar And China: A Special Relationship?... P. 206. 56 Min Zin. Burmese Attitude toward Chinese: Portrayal of the Chinese in Contemporary Cultural and Media Works, Journal of Current Southeast Asian Affairs, Vol. 31, No. 1, 2012, P. 119, URL: https://proxylibrary.hse.ru:2097/

doi/pdf/10.1177/186810341203100107

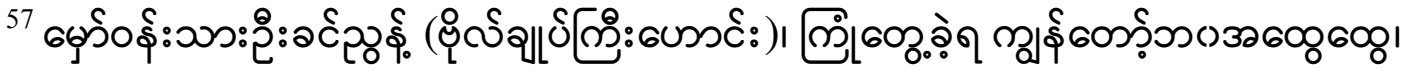

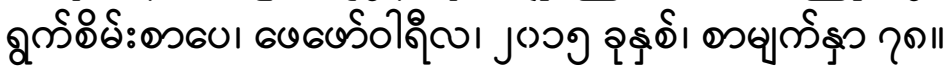

Статья поступила в редакцию 18.11.2020, принята к публикации 30.11.2020. 